\title{
NEW HOPE FOR GRASSLANDS NATIONAL PARK
}

MARY D. GILLILAND, 902 University Drive, Saskatoon, Saskatchewan. S7N

\section{The New Agreement}

For over 30 years the Saskatchewan Natural History Society (SNHS) has been a steadfast and strong advocate for protection of the original mixed grass prairie habitat of southwestern Saskatchewan through creation of a national park. In June 1981 an agreement was reached between the provincal and the federal governments to create such a park and land acquisition began. Two ranches totalling $140 \mathrm{~km}^{2}$ were purchased in the Frenchman River area. However, governments were unable to reach consensus on such issues as oil and gas exploration and water management. Land purchase ceased while officials from the Federal Government and the Province dealt with very basic disagreements.

On 23 September 1988 Federal Environment Minister Tom McMillan and Saskatchewan Minister of Parks, Recreation and Culture Colin Maxwell signed a new document, a unique agreement under which Saskatchewan will retain control of watercourses within the park but will cooperate with the Federal Government to ensure that standards are compatible with those in surrounding park lands. This compromise resulted in large partfrom the efforts of a coalition of nongovernment conservation organizations, in which the SNHS was a major player.

The new park will ultimately consist of two blocks, totalling some $900 \mathrm{~km}^{2}$. The proposed East Block includes the Killdeer Badlands and the West Block the Frenchman River country immediately southeast of Val Marie. Only a $340 \mathrm{~km}^{2}$ core area will be acquired immediately; the remaining lands are currently privately owned or leased and thus cannot be protected. The Saskatchewan Jvernment passed enabling legislati in August 1989, making it possible to nd acquisition to begin. Lands are be acquired on a willing-seller/willing-t ler basis over a period of some years By mid-August 26 landowners har $e$ quested property appraisals and se had begun negotiations to sell. As intendent and chief warden are in in Val Marie.

There are issues still to be res ed and discussions continue among ested government and nongovern int agencies and individuals. Interimg lelines will delineate a strategy for tegrated management of park lands $d$ ng the initial period; SNHS and other ested parties will closely monitor eir effectiveness.

\section{Grasslands Trust Fund}

At the September signing cerel ny in Regina, Mr. McMillan announce he enthusiastic acceptance by the $\mathrm{Fe}$ ral Government of a proposal made j ty by the Canadian Nature Feder on (CNF) and the Nature Conservan Canada to establish a trust fund fol no acquisition within the new park. Ac rd ing to Paul Griss, Executive Direc CNF, this "experiment in coopel on among the private sector, the $\mathrm{Fe}$ ral Government and nongovernment cies" will secure donations to be usi for speeding up land purchase. All $m$ es raised will be used to purchase la nothing will be spent on administrat 0 other costs. Every dollar raised $t$ he Fund will be matched by the $\mathrm{Fe}$ ral Government.

Lands acquired will be withit he approved park boundary but outsio he 
